PRACE NAUKOWE UNIWERSYTETU EKONOMICZNEGO WE WROCLAWIU

\title{
Justyna Fijałkowska
}

Społeczna Akademia Nauk

e-mail: jfijalkowska@spoleczna.pl

\section{Teresa Aldea}

Ecodea

e-mail: teresa@ecodea.co

\section{RAPORTOWANIE ZRÓWNOWAŻONEGO ROZWOJU MIAST A NORMA ISO 37120}

\section{REPORTING OF SUSTAINABLE DEVELOPMENT OF CITIES ACCORDING TO ISO 37120}

DOI: $10.15611 / \mathrm{pn} .2017 .478 .16$

JEL Classification: Q01, Q56, M14, 018, R29

Streszczenie: Miasta odgrywają istotną rolę w rozwoju i postępie cywilizacyjnym, wpływają w znacznym stopniu na swoje otoczenie. Ten wpływ może być pozytywny, ale też niekorzystny. Dlatego tak ważny jest przemyślany i zrównoważony rozwój miast, a dokonania realizowane w ramach tego rozwoju powinny podlegać pomiarowi, monitorowaniu i raportowaniu. O sukcesie miast decyduje m.in. transparentny sposób komunikowania działań, który można realizować poprzez raport zrównoważonego rozwoju. Celem artykułu jest podkreślenie zasadności raportowania zrównoważonego miast i wskazanie normy ISO 37120 jako istotnego wyznacznika dla zawartości informacyjnej takiego raportu. Przyjęta metodologia to studia literatury, dedukcja oraz analiza normy ISO 37120. We wnioskach wskazano korzyści, jakie miasto może osiągnąć poprzez aplikację normy. W pracy przyjęto normatywne podejście mające na celu wskazanie obszarów, w których najbardziej potrzebne są zmiany, i gdzie są one wykonalne.

Słowa kluczowe: raportowanie, zrównoważony rozwój, norma ISO 37120.

Summary: Cities play an important role in the development and progress of civilization, they influence their surroundings to a large extent. The success of cities is determined, among others, by the transparent way of communicating the achievements that can be realized through the sustainability report. The aim of this article is to emphasize the importance of sustainable reporting by cities and to show the ISO 37120 standard is an important determinant for the informative content of this report. The conclusions point the benefits that the city can achieve through the application of the ISO 37120 standard. In the paper the normative approach was adopted.

Keywords: reporting, sustainable development, ISO 37120. 


\section{Wstęp}

Miasta odgrywają ogromnie istotną rolę w zrównoważonym rozwoju globu. Stanowią jego ważny element. Są centrami pomysłów, handlu, kultury, nauki i rozwoju społecznego. Z drugiej strony istnieje jednak wiele wyzwań, którym miasta muszą sprostać; wśród nich znajdują się przeludnienie, brak środków finansowych dla zapewnienia odpowiedniego poziomu usług, niedobory mieszkań, ubóstwo mieszkańców, pogarszająca się infrastruktura, trudności z gospodarką odpadami komunalnymi i innymi zanieczyszczeniami. Miasta muszą stawiać czoła tym problemom i je przezwyciężać w taki sposób, by nie nadwyrężać dostępnych zasobów. Miasta mają ogromny potencjał, by budować dobrobyt, ale ich funkcjonowanie wiąże się też z ryzykiem bardzo negatywnego oddziaływania na ludzi i środowisko naturalne. Jednocześnie znaczenie miast rośnie. Są one domem dla ponad połowy mieszkańców całego globu, więc ich zrównoważony rozwój jest kluczowy dla przyszłości naszego świata. Miasta muszą i chcą się rozwijać, przyciągać nowych interesariuszy: mieszkańców, przedsiębiorców, studentów, inwestorów. Chcą budować swoją tożsamość i markę. Muszą więc czerpać dobre praktyki z zakresu zarządzania z biznesu. Podobnie jak przedstawiciele biznesu chcąc komunikować się ze swoimi interesariuszami, publikują raporty, w tym raporty zrównoważonego rozwoju, tak i miasta powinny wdrożyć praktykę sustainable reporting do swojego działania, jeśli chcą w sposób transparentny i użyteczny prowadzić dialog z interesariuszami, a jednocześnie zadbać o rozliczalność i przejrzystość podejmowanych działań i inicjatyw.

Celem artykułu jest podkreślenie istotności raportowania zrównoważonego rozwoju miast (RZRM) i wskazanie normy ISO 37120 jako istotnego wyznacznika dla zawartości informacyjnej takiego raportu. Przyjęta metodologia to studia literatury, dedukcja oraz analiza normy ISO 37120. We wnioskach podkreślono korzyści, jakie miasto może osiągnąć poprzez aplikację normy. W pracy przyjęto normatywne podejście mające na celu wskazanie obszarów, w których najbardziej potrzebne są zmiany i gdzie są one możliwe do zrealizowania.

\section{Pojęcie „zrównoważonego rozwoju” miast}

Pojęcie „zrównoważonego rozwoju” nie jest do tej pory precyzyjnie zdefiniowane. Najczęściej przytaczana definicja pochodzi z raportu „Nasza wspólna Przyszłość” [Raport Brundtland 1987], w którym czytamy: „Na obecnym poziomie cywilizacyjnym możliwy jest rozwój, w którym potrzeby obecnego pokolenia mogą być zaspokojone bez umniejszania szans przyszłych pokoleń na ich zaspokojenie". Termin zrównoważonego rozwoju coraz częściej używany jest również w kontekście miast ${ }^{1}$.

${ }^{1} \mathrm{~W}$ artykule tym posługujemy się pojęciami „zrównoważony rozwój miast” i ,zrównoważone miasto" w sposób wymienny, odnosząc się do szerokiej dyskusji na ten temat w literaty [np. Richardson 1994; Maclaren 1996] dopuszczającej takie podejście, ze wskazaniem, że różnica odnosi się głównie do stanu dynamicznego pierwszego z nich. 
„Miasta są największą innowacją w dziejach ludzkości. Miasta są trwalsze od państw, trwają w dziejach i jednocześnie zmieniają się, nie tracąc jednak swojej istoty" [Bendyk i in. 2016, s. 123]. Dziś miasta są domem dla ponad połowy światowej populacji. Urbanizacja wymieniana jest jako jeden z sześciu megatrendów (obok rozwoju gospodarki i społeczeństwa cyfrowego, wzrostu przedsiębiorczości, globalizacji rynku, wykorzystywania surowców i zasobów naturalnych oraz zmiany w systemie ochrony zdrowia), które jako czynniki połączone zmienią gospodarkę, kulturę i społeczeństwo w czasie najbliższych 20-30 lat i przesądzą o rozwoju świata [Megatrendy 2015]. Zgodnie z badaniem przeprowadzonym przez firmę Ernst\&Young, w 2015 r., w miastach mieszkało 54\% ludności świata, a w 2050 r. ma to być ponad $66 \%$; oznacza to konieczność prowadzenia zrównoważonego rozwoju miast, budowy megapolis wyposażonych w sieć dróg i autostrad, infrastruktury przewozów powietrznych, wodnych, inwestycji w zasoby energetyczne, dobrze rozwinięte sieci teleinformatyczne oraz infrastrukturę komunalną. Kosztować to będzie globalnie 60-70 bln USD, jednak się opłaci, już bowiem obecnie 750 największych miast świata generuje 57\% globalnego PKB [Megatrendy 2015]. Miasta są odpowiedzialne za tworzenie zdecydowanej większości produkcji gospodarczej świata [KPMG 2012, s. 2].

Z drugiej strony należy pamiętać, że wpływ miast na społeczeństwo i środowisko może być też negatywny. Miasta emitują ponad 70\% światowych gazów cieplarnianych, używają 80\% światowej energii [KPMG 2011, s. 6]. Przyczyniają się do zatrucia powietrza i wody. Ponad $80 \%$ Europejczyków zamieszkujących tereny zurbanizowane oddycha powietrzem wykraczającym pod względem zanieczyszczeń ponad normy ustanowione przez WHO, a z powodu złej jakości powietrza corocznie na świecie umiera ok. 3,5 mln osób. Miasta są też enklawami biedy: $828 \mathrm{mln}$ ludzi żyje dziś w slumsach i liczba ta nie przestaje rosnąć [UN Global Compact 2016, s. 6-7].

Jak podkreślono w raporcie UN Global Compact, „wyzwania, przed którymi stoją miasta, mogą zostać przezwyciężone w sposób, który pozwoliłby im na dalszy rozkwit z jednoczesną poprawą $\mathrm{w}$ gospodarowaniu zasobami, redukcji zanieczyszczeń i biedy. Przyszłość, której pragniemy, to miasta oferujące możliwości dla każdego, z dostępem do podstawowych usług, energii, zasobów mieszkalnych i transportu" [Global Compact UN 2016, s. 7]. Jest to możliwe poprzez przyjęcie filozofii „zrównoważonego rozwoju” miast.

Idea zrównoważonego rozwoju miast powstała jako inicjatywa będąca odpowiedzią na degradację zaistniałą w otoczeniu miast w XX w. [Hassan, Lee 2014, s. 1271]. Pojęcie „miasta zrównoważonego” może odnosić się do miasta, które spełnia społeczne, kulturowe, środowiskowe oraz polityczne wymogi, realizując jednocześnie cele ekonomiczne i wiążące się z zasobami fizycznymi, zapewniając równy

${ }^{2}$ Niektóre źródła podają większe wartości, np. zgodnie z raportem ONZ do roku 2050 miasta będą zamieszkiwane przez ponad 2/3 całej ludności świata [United Nations 2014]. 
dostęp mieszkańców do wszelkich usług, bez nadszarpywania zasobów innych miast i regionu [Rogers 1997, s. 26]. Zrównoważony rozwój miast odnosi się do trzech głównych aspektów wymienionych i scharakteryzowanych w tabeli 1.

Tabela 1. Podstawowe aspekty zrównoważonego rozwoju miasta

\begin{tabular}{|l|l|}
\hline $\begin{array}{c}\text { Aspekty } \\
\text { zrównoważonego } \\
\text { rozwoju miast }\end{array}$ & \multicolumn{1}{c|}{ Charakterystyka } \\
\hline $\begin{array}{l}\text { Zrównoważony } \\
\text { rozwój } \\
\text { środowiskowy }\end{array}$ & $\begin{array}{l}\text { Urbanizacja wywiera bezprecedensową presję na kluczowe obszary gospodarki } \\
\text { energetycznej, wodnej oraz gospodarki odpadami. Zmiany klimatyczne } \\
\text { i degradacja środowiska podwyższają koszty rozwoju infrastruktury, związane } \\
\text { np. z faktem, że znacząca liczba największych miast na świecie znajdują się } \\
\text { w strefach przybrzeżnych i zalewowych, w związku z czym są one szczególnie } \\
\text { narażone na skutki podniesienia się poziomu morza spowodowane przez zmiany } \\
\text { klimatyczne i muszą się im przeciwstawiać. }\end{array}$ \\
\hline $\begin{array}{l}\text { Zrównoważony } \\
\text { rozwój finansowy }\end{array}$ & $\begin{array}{l}\text { W wyniku tego, że zasoby stają się coraz rzadsze, ceny surowców rosną, } \\
\text { a konkurencja staje się bardziej intensywna, konieczne staje się odpowiedzialne } \\
\text { i właściwe przygotowywanie budżetów miast, biorące pod uwagę zwiększające } \\
\text { się koszty bieżącej działalności. }\end{array}$ \\
$\begin{array}{l}\text { Z szacunków wynika, że w ciągu najbliższych 25 lat na świecie potrzebne będzie } \\
\text { ponad 40 bln USD na inwestycje, z których zdecydowana większość zostanie } \\
\text { przeznaczona na rozwój infrastruktury miejskiej i jej utrzymanie. Wyzwaniem } \\
\text { dla administracji jest poszukiwanie nowych źródeł finansowania i sposobów } \\
\text { zabezpieczenia i obsługi zadłużenia. Dzisiejsze sposoby finansowania } \\
\text { podejmowanych działań na szczeblu miast mogą być znaczącym obciążeniem } \\
\text { dla kolejnych pokoleń. Zrównoważone finansowanie wiąże się również } \\
\text { z pozyskiwaniem funduszy i zarządzaniem finansowaniem dotyczącym } \\
\text { rozwiązywania wielu problemów, z którymi borykają się miasta, } \\
\text { np. z bezrobociem, bezdomnością, ubóstwem. }\end{array}$ \\
$\begin{array}{l}\text { Administratorzy i osoby odpowiedzialne za planowanie miejskie muszą } \\
\text { odpowiednio zaprojektować i zbudować oraz rozwijać już istniejącą } \\
\text { infrastrukturę miejską; jednocześnie muszą zadbać o sposoby jej utrzymania, } \\
\text { modernizacji, a finalnie o właściwą jej likwidację. Elementem mającym duże } \\
\text { znaczenie w kontekście rozwoju miast w kierunku zrównoważonego rozwoju } \\
\text { jest budownictwo niskoenergetyczne, w tym pasywne. }\end{array}$ \\
\hline $\begin{array}{l}\text { Zrównoważony } \\
\text { rozwój aktywóm } \\
\text { materialnych }\end{array}$ \\
\hline
\end{tabular}

Źródło: opracowanie własne na podstawie [KPMG 2012].

Miasta stają dziś przed wyzwaniem realizowania zasad zrównoważonego rozwoju, zakładającego efektywne wykorzystywanie zasobów naturalnych, oraz tych, które są wynikiem działalności człowieka. Przez wielu miasta uważane są za główny obszar i podstawową skalę działalności, w której ramach można realizować koncepcję zrównoważonego rozwoju [Glaeser 2011; Johnston i in. 2013]. Jednocześnie w literaturze podkreśla się, że nawet wzmożone inicjatywy na rzecz rozwoju zrównoważonego, przy braku raportowania rezultatów tych działań, stanowią barierę i ograniczenie dla możliwości uznania danego miasta za zrównoważone [Maclaren 1996, s. 184]. 


\section{Raportowanie zrównoważonego rozwoju miast (RZRM)}

Źródłem informacji o rozwoju zrównoważonym miast może stać się specjalnie do tego celu stworzony raport. Zgodnie z Global Reporting Initiative (GRI) „raportowanie kwestii zrównoważonego rozwoju polega na mierzeniu, ujawnianiu oraz ponoszeniu odpowiedzialności względem wewnętrznych i zewnętrznych interesariuszy za wyniki i wydajność w zakresie adresowanych kwestii” [GRI 2002-2006, s. 3]. Ma ono za zadanie zwiększanie transparentności podejmowanych działań. „Pilność i powaga ryzyka i zagrożeń dla wspólnego zrównoważonego rozwoju, wraz ze zwiększającymi się szansami i możliwościami wyboru sprawiają, iż transparentność w odniesieniu do kwestii ekonomicznych, środowiskowych i społecznych stanie się kluczowym składnikiem relacji z interesariuszami, decyzji inwestycyjnych oraz pozostałych interakcji zachodzących na rynku" [GRI 2002-2006, s. 2].

Praktyka RZRM na świecie jest coraz bardziej powszechna. Celem RZRM jest dostarczenie mieszkańcom, gościom, inwestorom, studentom i innym zainteresowanym kompleksowej i rzetelnej wiedzy z zakresu uwarunkowań ekonomicznych, środowiskowych i społecznych określonego miasta. Dzięki procesowi raportowania miasta mogą osiągnąć następujące korzyści:

1) tworzenie wizerunku opartego na wartościach;

2) zintegrowanie mieszkańców i wzrost ich zaangażowania we wspólny rozwój miasta, tworzenie współodpowiedzialności wśród mieszkańców;

3) promocja miasta, regionu oraz władz miasta w skali krajowej i międzynarodowej;

4) budowanie marki miasta i przewagi konkurencyjnej;

5) ułatwienie dialogu pomiędzy władzami miasta a różnymi grupami interesariuszy;

6) pozyskanie nowych inwestorów i partnerów biznesowych;

7) przyciąganie i utrzymanie najbardziej utalentowanych specjalistów, ludzi nauki, sztuki i innych profesji.

RZRM może przełożyć się na wymierne korzyści dla miasta, w tym finansowe. Zainteresowanie inwestorów raportami zrównoważonego rozwoju systematycznie rośnie. Obecnie szacuje się, że $67 \%$ z nich zawsze korzysta z informacji niefinansowych przy podejmowaniu decyzji inwestycyjnych, a $89 \%$ uważa je za główne źródło informacji [ACCA 2013, s. 5].

W związku z tym, że RZRM nie jest dla miast wymagany prawnie i jest publikowany na zasadzie wolontariatu, również jego zawartość jest co do zasady dowolna ${ }^{3}$. $\mathrm{Z}$ faktu tego korzysta wiele miast i w sposób dość dowolny prezentuje informacje,

${ }^{3}$ Pojawiają się już pierwsze głosy dotyczące obowiązku raportowania zrównoważonego miast; Sułkowski [2016] wskazuje, że w Stanach Zjednoczonych w związku z faktem, że tamtejsze miasta na szeroką skalę emitują papiery wartościowe, dane dotyczące zrównoważonego rozwoju tych miast powinny być ujawniane i że wymóg prawny w tym zakresie jest elementem pragmatycznej polityki publicznej oraz leży w interesie wszystkich zainteresowanych stron. 
arbitralnie uznane za istotne dla interesariuszy raportu. Generalnie można spotkać dwa rodzaje raportowania odnoszącego się do zrównoważonego rozwoju i zagadnień społecznych oraz środowiskowych: podejście bazujące na pomiarze wskaźnikowym [Atkinson 2000; Veleva i in. 2001] oraz raportowanie opierające się wyłącznie na opisie, deskrypcji, narracji [Agger 2010]. To drugie spotykane jest często w raportach zrównoważonych miast [Magee i in. 2013, s. 226]. W badaniu analizującym 60 raportów RZRM w Stanach Zjednoczonych [Moore i in. 2016] w żadnym z opublikowanych dokumentów nie zastosowano jakiegokolwiek zestawu wskaźników. Stąd ich porównywalność i wnioskowanie były bardzo utrudnione. W odniesieniu do podejścia bazującego na wskaźnikach należy zaznaczyć, że i w tym przypadku spójność i porównywalność informacji są bardzo utrudnione. W praktyce stosowane są różne zestawy wskaźników, tworzone indywidulanie dla konkretnych miast; takie zestawy istnieją np. dla Taipei [Huang i in. 1998] oraz dla Orlando [Atkinson i in. 1997]. Ponadto tworzone są zestawy dla regionów, państw. Zhang [2002] zaproponował tzw. Urban Sustainability Index (USI) dla miast z Chin, we Włoszech stosowany jest system wskaźników nazwany Ecosistema Urbano Performance Index, w Wielkiej Brytanii Sustainable Cities Index. Organizacja the United Nations Center for Human Settlements (HABITAT) zaproponowała City Development Index $(\mathrm{CDI})^{4}$. Kilkanaście miast na świecie stosuje wytyczne GRI dla RZRM; są to np. Chicago, Atlanta, Melbourne, Dublin oraz Warszawa, która przygotowała pierwszy na świecie raport zrównoważono rozwoju zgodny z wytycznymi GRI G4 za rok 2013, a w 2014 r., przygotowując drugi RZRM, wykorzystała zarówno wytyczne, jak i wskaźniki normy ISO37120. Powstanie raportu dla Warszawy za rok 2014 jest efektem współpracy samorządu i sektora naukowego: zespołu ze studiów podyplomowych Menedżer CSR w Collegium Civitas.

Dobrą praktyką byłoby, gdyby tak jak w przypadku przedsiębiorstw, dla raportowania zrównoważonego zaczęto powszechnie stosować zunifikowane wytyczne lub zestawy wskaźników, umożliwiające uzyskanie spójności, kompletności oraz porównywalności w czasie i przestrzeni ujawnianych informacji. Odpowiedzią na wyzwanie ujednolicenia praktyk RZRM, poza wytycznymi GRI, jest przygotowanie raportu w oparciu o zestaw wskaźników zaproponowanych przez normę ISO 37120 , która mogłaby stać się bazą dla zunifikowania wyżej wymienionych podejść do pomiaru i raportowania działań miast.

\subsection{Norma ISO 37120}

Brak spójnej i odpowiednio przygotowanej normy oceny dokonań miast przy jednocześnie zwiększającym się zainteresowaniu funkcjonowaniem miast przez różne grupy interesariuszy spowodowało podjęcie przez Międzynarodową Organizację Normalizacyjną decyzji o stworzeniu normy ISO 37120. Oparta jest ona na zestawie

\footnotetext{
${ }^{4}$ Więcej na temat równych zestawów wskaźników zrównoważonego rozwoju miast zob. [Singh i in. 2009; Xing i in. 2009].
} 
wskaźników, które zostały opracowane i przetestowane przez Global City Indicators Facility (siostrzaną organizację WCCD, World Council on City Data) oraz jej ponad 250 miast członkowskich na całym świecie. WCCD natomiast, we współpracy z Global Cities Registry ${ }^{\mathrm{TM}}$, opracowała pierwszy system certyfikacji ISO 37120.

Norma ISO 37120 została wprowadzona 15 maja 2014 r., podczas światowego szczytu miast organizowanego przez Global City Indicators Facility. 16 marca 2015 r. Polski Komitet Normalizacyjny przyjął normę ISO 37120:2015-03 i nadał jej polską nazwę: „Zrównoważony rozwój społeczny - wskaźniki usług miejskich i jakości życia". Norma ta ma na celu umożliwienie w jednolity sposób oceny funkcjonowania oraz dokonań zaangażowanych miast i ma pozwolić na szczegółową ocenę ich sfer działalności. Użyte kryteria mają umożliwić obserwację i ocenę zmian w ujęciu corocznym, w tym również porównania z innymi miastami. Potencjalnymi użytkownikami tej normy, w intencji jej twórców, mają być zarządzający miastem, politycy, badacze, przedsiębiorcy czy planiści. Norma obejmuje 100 wskaźników dotyczących 17 obszarów tematycznych, podzielonych na następujące kategorie:

- Bezpieczeństwo

- Woda i warunki sanitarne

- Edukacja

- Energia

- Finanse

- Gospodarka

- Pożarnictwo i reagowanie w sytuacjach awaryjnych

- Planowanie przestrzenne

- Rekreacja

- Ścieki

- Odpady

- Środowisko

- Telekomunikacja i innowacja

- Transport

- Pomoc społeczna

- Zarządzanie/ład organizacyjny

- Zdrowie

Norma ta koncentruje się na trzech głównych aspektach; transparentności w prezentacji danych, rozliczalności $\mathrm{z}$ podejmowanych decyzji oraz innowacyjności w stawaniu się światowym liderem w realizowaniu najwyższych standardów dostarczania usług przez miasta. Norma dzieli się na część niezbędną do uzyskania certyfikatu oraz wymogi dodatkowe, fakultatywne. Określa i definiuje sposób pomiaru poszczególnych wskaźników oraz wskazuje, skąd czerpać potrzebne dane. W ramach normy nie określono natomiast wartości minimalnych, które miasto musi osiągnąć.

Miasta, które uzyskały certyfikat ISO 37120, są dodawane do bazy organizacji Global Cities Registry ${ }^{\mathrm{TM}}$ na okres 1 roku. Po zakończeniu tego okresu muszą po- 
nownie przejść proces certyfikacji. Miasta mogą otrzymać różne poziomy certyfikacji w oparciu o liczbę zgłoszonych i zweryfikowanych wskaźników, zgodnie z normą ISO 37120:

- aspiracyjny - główne wskaźniki, od 30 do 45;

- brązowy - 46 głównych plus od 0 do 13 wskaźników szczegółowych;

- srebrny - 46 głównych plus od 14 do 29 wskaźników szczegółowych;

- złoty - 46 głównych plus od 30 do 44 wskaźników szczegółowych;

- platynowy - 46 głównych plus od 45 do 54 wskaźników szczegółowych.

W bazie WCCD Global City Registry ${ }^{\mathrm{TM}}$ znajduje się obecnie 46 miast. Zestawienie miast, które uzyskały status platynowy i które mogłyby stać się wzorem najlepszych praktyk $\mathrm{w}$ pomiarze zrównoważonego rozwoju, przedstawiono $\mathrm{w}$ tabeli 2 .

Tabela 2. Miasta o platynowym poziomie certyfikacji ISO 37120

\begin{tabular}{|c|c|c|}
\hline Miasto & Państwo & Rok przyznania statusu platynowego \\
\hline Surrey & Kanada & 2016 \\
\hline Zagrzeb & Chorwacja & 2016 \\
\hline Koprivnica & Chorwacja & 2016 \\
\hline Cambridge & Kanada & 2016 \\
\hline Eindhoven & Holandia & 2016 \\
\hline Heerlen & Holandia & 2016 \\
\hline San Diego & USA & 2016 \\
\hline Saint-Augustin-de-Desmaures & Kanada & 2016 \\
\hline Amman & Jordan & 2015 i 2014 \\
\hline Toronto & Kanada & 2015 i 2014 \\
\hline Makkah & Arabia Saudyjska & 2015 \\
\hline Guadalajara & Meksyk & 2015 \\
\hline Boston & USA & 2015 i 2014 \\
\hline Taipei & Taiwan & 2015 \\
\hline Shawiningan & Kanada & 2015 \\
\hline Dubai & Arabia Saudyjska & 2015 i 2014 \\
\hline Melbourne & Australia & 2015 \\
\hline Makati & Filipiny & 2015 i 2014 \\
\hline Buenos Aires & Argentyna & 2015 \\
\hline Valencia & Hiszpania & 2015 \\
\hline Leon & Meksyk & 2015 \\
\hline London & UK & 2015 i 2014 \\
\hline Vaughan & Kanada & 2015 \\
\hline Los Angeles & USA & 2015 \\
\hline Rotterdam & Holandia & 2014 \\
\hline Barcelona & Hiszpania & 2014 \\
\hline
\end{tabular}

Źródło: opracowanie własne. 
Norma ISO 37120 ma za zadanie ułatwienie dostępu do porównywalnych danych, umocnienie przejrzystości oraz ma stać się nowym narzędziem analizy dla podejmowanych decyzji, w tym inwestycyjnych. Oczekuje się, że informacje uzyskane dzięki zastosowaniu tej normy będą publikowane, tak by mogły stać się dostępne dla szerszego grona interesariuszy. Norma ISO 37120 może więc być traktowana jako narzędzie jednolitego sposobu raportowania stanu rozwoju miasta.

Główne korzyści zastosowania spójnego sposobu raportowania wskaźników dotyczących zrównoważonego rozwoju miasta, bazujących np. na normie ISO 37120, to:

1) lepsza możliwość zarządzania miastem, z uwzględnieniem pomiaru dokonań, skuteczności działań; stąd również większa szansa na wprowadzenie zarządzania i planowania nastawionego na długoterminowy rozwój zrównoważony;

2) możliwość dokonywania porównań w czasie i przestrzeni (pozycjonowanie miast);

3) większa przejrzystość informacji, powodująca m.in. zmniejszenie przepaści pomiędzy społeczeństwem obywatelskim a władzą;

4) większa wiedza o mieście, zarówno w skali globalnej, jak i lokalnej;

5) dostęp do danych, w tym możliwość zwiększenia wiarygodności tych danych poprzez audyt i/lub ich weryfikację przez instytucje zewnętrzne;

6) większa przejrzystość działań i możliwość rozliczalności władz;

7) większa wiarygodność na rynkach finansowych, większe szanse na pozyskanie inwestorów, wprowadzenie programów finansowania działań.

Z punktu widzenia finansów wdrożenie normy ISO 37120 i raportowanie uzyskanych informacji pomaga we wzmacnianiu wiarygodności miasta w oczach instytucji finansowych oraz inwestorów. Umiejętność liczenia parametrów funkcjonowania miasta, określania wyzwań strategicznych, ewaluacji dokonań i transparentnego upubliczniania tych informacji jest bardzo pozytywnie odbierana zarówno przez inwestorów, jak i instytucje finansowe. Posiadanie certyfikatu ISO 37120 może być przydatne $\mathrm{w}$ staraniach o dofinansowanie miasta $\mathrm{z}$ funduszy unijnych również w związku z tym, że przy tworzeniu tej normy brały udział Komisja Europejska i Europejski Bank Światowy, organizacje przyznające te fundusze.

\section{Zakończenie}

Miasta odgrywają szczególnie ważną rolę w dzisiejszym świecie; ich wpływ może być pozytywny, ale też niekorzystny. Dlatego tak ważny jest przemyślany i zrównoważony rozwój miast, a dokonania realizowane w ramach tego rozwoju powinny podlegać pomiarowi, monitorowaniu i raportowaniu.

Wprowadzenie normy ISO 37120 i raportowanie wskaźników świadczą o zintegrowanym zarządzaniu miastem, opierającym się na koordynacji kluczowych ob- 
szarów polityki miejskiej z punktu widzenia przestrzeni, przedmiotu działania i czasu przy aktywnym zaangażowaniu, m.in. społeczeństwa i innych interesariuszy, wiąże się z szeregiem korzyści dla miast i może mieć pozytywny wpływ na decyzje wszystkich jego interesariuszy.

\section{Literatura}

ACCA, 2013, What do investors expect from non-financial information?, http://www.accaglobal.com/ content/dam/acca/global/PDF-technical/sustainability-reporting/tech-tp-wdir.pdf (8.01.2017).

Agger A., 2010, Involving citizens in sustainable development: Evidence of new forms of participation in the Danish Agenda 21 schemes, Local Environment, no. 15 (6), s. 541-552.

Atkinson G., 2000, Measuring corporate sustainability, Journal of Environmental Planning and Management, 43 (2), s. 235-252.

Atkinson G.D., Dubourg R., Hamilton K., Munasignhe M., Pearce D.W., Young C., 1997, Measuring Sustainable Development: Macroeconomics and the Environment, Edward Elgar, Cheltenham.

Bendyk E., Hausner J., Kudłacz M., 2016, Miasto - Idea - Nowe podejście do rozwoju miast, [w:] Open Eyes Book, Fundacja Gospodarki i Administracji Publicznej, Kraków, s. 119-167.

Glaeser E.L., 2011, Triumph of the City: How Our Greatest Invention Makes Us Richer, Smarter, Greener, Healthier, and Happier, Penguin Press, New York.

Global Compact UN, 2016, Zrównoważone miasta. Zycie w zdrowej atmosferze, http://ungc.org.pl/wp-content/uploads/2016/10/Raport-Zr\%C3\%B3wnowa\%C5\%BCone-miasta.pdf (10.01.2017).

GRI, 2002-2006, Wytyczne do raportowania kwestii zrównoważonego rozwoju, https://www.globalreporting.org/.../GRI-G3-Polish-Reporting-Guidelines.pdf (10.01.2017).

Hassan A., Hyowon L., 2015, The paradox of the sustainable city: definitions and examples, Environment, Development and Sustainability: A Multidisciplinary Approach to the Theory and Practice of Sustainable Development, vol. 17, issue 6, s. 1267-1285.

Huang S.L., Wong J.H., Chen T.C., 1998, A framework of indicator system for measuring Taipei's urban sustainability, Landscape and Urban Planning, no. 42, s. 15-27.

Johnston S., Nicholas S., Parzen J., 2013, The Guide to Greening Cities, Island Press, Washington, DC.

KPMG, 2011, Insight: Urbanization, KPMG International, https://home.kpmg.com/xx/en/home/insights/.../urbanization.html (10.01.2017).

KPMG, 2012, Insight: Cities Infrastructure: a report on sustainability, https://home.kpmg.com/content/dam/kpmg/pdf/2012/05/Cities-Infrastructure-a-report-on-sustainability.pdf (10.01.2017).

Maclaren V., 1996, Urban Sustainability Reporting, Journal of the American Planning Association, no. 62 (2), Spring, s. 184-202.

Magee L., Scerri J., James P., Thom J., Padham L., Hickmott S., Deng H., Cahill F., 2013, Reframing social sustainability reporting: towards an engaged approach, Environment, Development and Sustainability: a multidisciplinary approach to the theory and practice of sustainable development, vol. 15 , no. 1 , s. $225-243$.

Megatrendy, 2015, Ernst \&Young, http://ey.media.pl/pr/294826/raport-ey-szesc-globalnych-megatrendow-ktore-wywra-wplyw-na-spoleczenstwa-kulture-i-gospodarke (10.02.2017).

Moore W., Baker C., Poznanski P., 2016, Sustainability Reporting by U.S. Cities: A Review of Practice and Theory, Journal of Accounting, Ethics \& Public Policy, vol. 17, no. 4, s. 877-898.

Raport Brundtland, 1987, Our Common Future, Oxford University Press, The World Commission on Environment and Development, Oxford.

Richardson N., 1994, Making Our Communities Sustainable: The Central Issue is Will', Ontario Round Table on Environment and Economy, Sustainable Communities Resource Package. 
Rogers R., 1997, Cities for a small planet, Faber and Faber Limited, London.

Sułkowski A., 2016, City Sustainability Reporting: An Emerging \& Desirable Legal Necessity, 33 Pace Environmental Law Review, no. 278, http://digitalcommons.pace.edu/pelr/vol33/iss2/4 (8.02.2017). Singh R.K., Murty H.R. Gupta S.K. Dikshit A.K., 2009, An overview of sustainability assessment methodologies, Ecological Indicators, vol. 9, issue 2, March, s. 189-212.

United Nations, 2014, Worlds Urbanization Prospects, https:/esa.un.org/unpd/wup/Publications/Files/ WUP2014-Highlights.pdf (5.02.2017).

Veleva V., Hart M., Greiner T., Crumbley C., 2001, Indicators of sustainable production, Journal of Cleaner Production, no. 9 (5), s. 447-452.

Xing Y., Horner R.M.W., El-Haram M.A., Bebbington J., 2009, A framework model for assessing sustainability impacts of urban development, Accounting Forum, no. 33, s. 209-224.

Zhang M., 2002, Measuring urban sustainability in China, ThelaThesis, Amsterdam. 